\title{
Palavra Evento e Práxis Libertadora: a eclesiologia de Karl Barth e sua contribuição para a teologia latinoamericana
}

\author{
Orientador: Ana Maria de Azeredo Lopes Tepedino \\ Doutorando: Manoel Bernardino de Santana Filho \\ Área de Concentração: Teologia Sistemático-Pastoral \\ Linha de Pesquisa: Fé e Cultura
}

A teologia de Karl Barth se caracteriza por afirmar o caráter fenomenal da manifestação de Deus na história. Ela só é verdadeiramente Palavra de Deus quando toca existencialmente o ser humano. É a palavra que acontece a cada instante levando o indivíduo a uma crise e consequentemente a uma tomada de posição. Ela acontece plenamente em Jesus Cristo, Aquele que propicia o encontro entre o eterno e o temporal. Neste trabalho o autor procurará mostrar a influência desta teologia nos teólogos latino-americanos especialmente naqueles pertencentes à Teologia da Libertação. O conceito barthiano de palavra como evento encontra sua correspondência na práxis histórica que privilegia a ação antes que a teoria. Barth trabalha com o método prática $>$ teoria $>$ prática. Ele parte da experiência e faz da teologia um segundo momento na prática eclesial. A partir daí retorna para a prática. Esse método encontra-se presente na metodologia teológica da América Latina.

Palavras-chave: Eclesiologia, Reforma, Ação Profética, Socialismo Religioso. 